\section{Warburg's wars}

\author{
Walter Gratzer
}

Ein Genie Irrt Seltener . . . Otto Heinrich Warburg: Ein Lebensbild in Dokumenten. By Petra Werner. Akademie Verlag: 1991. Pp. 476 DM74.

A. J. BALFOUR avowed in old age that the chief lesson life had taught him was that nothing matters very much and hardly anything matters at all. The passing years brought no such consolation to Otto Warburg, for to him everything that touched his life and work mattered acutely until the end. His career of nearly 70 years was riven by disputes, pursued with a passion that was seldom slaked even by an adversary's death. That Warburg was withal a great man, a titan of modern biology, is not in doubt, for much of what is today taken for granted in biochemistry, cell biology and the analytical techniques on which they depend derives from his work.

The young Warburg grew up in a scientific hothouse presided over by his father, Emil, an illustrious physicist, intimate of Einstein and a friend of his son's first patron, Emil Fischer. Warburg revered Fischer, whose statue in bronze he caused to be erected half a century later outside his new research institute. Almost everyone else who crossed his path he regarded as fair game, starting in his twenties with the venerable Jacques Loeb, who met his vituperation with saintly forbearance. Warburg's career was already in full flower when the Kaiser's war intervened and he volunteered for the cavalry, in which he served for four years. Like J. B. S. Haldane, he seems to have been one of the few participants who thoroughly enjoyed the war, but where Haldane was described by his commander as the bravest but dirtiest officer in his unit, Warburg took especial pleasure in the martial glamour and the dashing uniform of his regiment of Uhlans. His mother, appalled at the lengthening odds against her son's survival in the cataclysm of 1918, appealed to Einstein to intercede for his release and eventually, but only shortly before the armistice, permission came for Warburg to return to his laboratory on the specious grounds that his work on photosynthetic algae might lead to a new food source for a starving populace.

Petra Werner has put together an absorbing commentary on Warburg's life and his social and scientific milieu in letters and documents. She has a telling quotation from a letter in which he extols the military virtues. The army taught him, he wrote, how to deal with men and to obey commands - and by implication how to run his laboratory, where indeed orders were orders and no deviations from the director's code of conduct were countenanced. As a bachelor, with his own batman to look after him, Warburg had no sympathy with the demands of family life on his subordinates. Illness was no excuse for absence and death barely so: visits to the doctor, it was decreed, must wait until the annual vacation. Warburg's student, the future Nobel laureate Hans Krebs, was brusquely dismissed and advised to find himself another vocation, probably because he had remonstrated with the chief

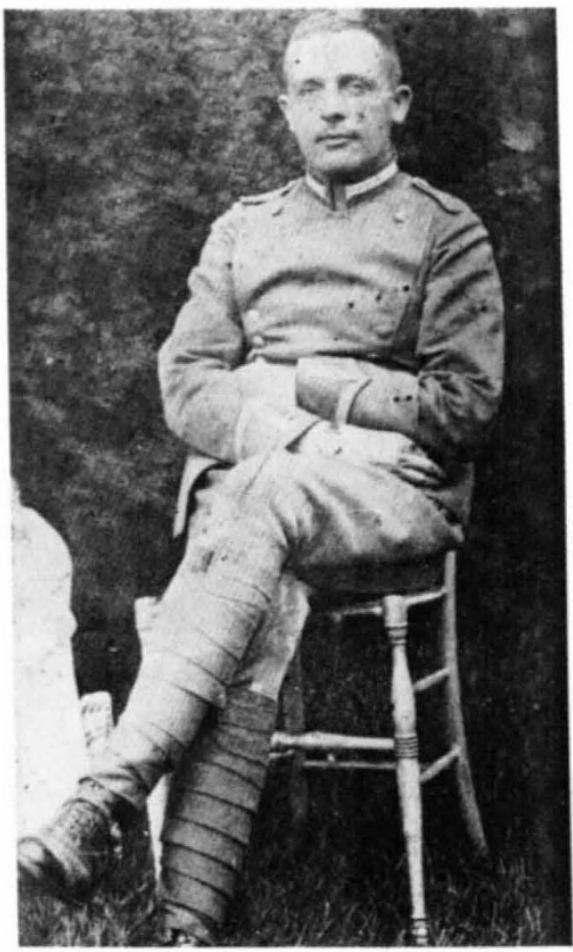

Enjoying the war - Warburg served for four years in the cavalry.

about the abusive tone of his criticisms of some work by Keilin and Wieland.

Warburg was on poor terms with his fellow directors at the Kaiser-Wilhelm Institute; he regarded himself, generally no doubt with reason, as their intellectual superior and he made little attempt to conceal his opinion. Foreign visitors were, however, welcome in the laboratory and he was willing to learn from physicists and physical chemists, for he regarded science as indivisible and the barriers between disciplines as otiose. When he feared that he might be overextending the resources of his laboratory, he sought Walther Nernst's advice on whether he should concentrate on photosynthesis or on cancer; cancer, the guru pronounced, because photosynthesis after all works perfectly well. In the event he continued with both, and developed the oxidative theory of malignancy, to which he cleaved to the end of his life. His high-pressure oxygen therapy for cancer was widely adopted in Germany and the enthusiasm for it, whipped up by the press, made him a public figure. It was not the only nostrum to which he lent his name. The waters of the European spas were still widely held to have all but miraculous curative properties, probably in the main because of the consuming Central European preoccupation with bowel motions. (It used to be said that Karlsbad was built on undelivered faeces.) Warburg's association with the pharmaceutical company Schering led to the marketing, with his endorsement, of tablets that would generate in the glass either Karlsbad or Marienbad water. The uninhibited advertising literature, bearing Warburg's name and fulsome testimonials from satisfied customers, makes curious reading.

Success was not enough for Warburg: his rivals had to be seen to fail. The Nobel prize for Wieland enraged him. The prize, he wrote to his sister, signified nothing, awarded as it was by no more than a gang of drunken Swedes. Petra Werner documents the celebrated episode of high comedy when The Times, mistaking Warburg for his namesake and distant relative, a professor of botany at the University of Jerusalem, printed an obituary, also taken up by Nature. The piece failed, in Warburg's view, to do his achievements justice and omitted even to credit him with the discovery of the "old yellow enzyme" of intermediary metabolism. He is believed to have written a strongly worded letter to The Times.

The rise of the Nazi party caused a swift exodus of scientists from Germany. Warburg regarded flight as undignified and stayed put. At first he offered at least passive resistance to the depredations of the regime, but as dissent grew more dangerous he became increasingly concerned to protect his position. He had never acknowledged his Jewish ancestry, and now demurred when his sister begged for help for her husband, the distinguished chemist von Wartenberg, who had been dismissed for having a half-Jewish wife. Warburg now found that upright Germans were increasingly avoiding his company. Meyerhof, whom he respected, was denounced by the odious Richard Kuhn (then an institute director, and still one after the war) for harbouring non-Aryan research assistants, and left for the United States. Shortly thereafter, Warburg was relieved of his position, but a little later he was reinstated. Werner gives reasons for believing that he owed his survival to the conviction of highly placed patrons that he would (as he had himself repeatedly claimed) shortly find a cure for cancer and thus shed glory on German science as well as promoting their own longevity;

NATURE · VOL $356 \cdot 16$ APRIL 1992 
Hitler, moreover, was known to have a morbid fear of cancer and may himself have sanctioned Warburg's reclassification from half-Jewish to quarter-Jewish to circumvent the race laws. At all events, he spent a tranquil war, pursuing his researches, and was permitted even to maintain his stable of thoroughbreds.

In 1945 the Russians arrived and Warburg levanted to his country house on the island of Rügen, leaving the surviving members of his staff to protect the institute as best they could against the rapine of the occupiers. This act of abnegation caused much rancour. One of the most absorbing passages of the book is a long extract from the diary of Warburg's assistant, Lüttgens, chronicling the life of the institute during this tumultuous period. In the end the contents of the laboratory were packed into crates and shipped off to Russia. Left without the means to carry on experimental science, Warburg dedicated himself to writing two monographs, full of invective against his scientific rivals. There followed a disastrous visit to the United States at the invitation of Robert Emerson, who hoped that the issue of the quantum yield of photosynthesis, which had become a running sore, could be cleared up by collaborative experimental work in Chicago. Warburg could not bring himself to concede defeat and left in a huff. The death of his old adversary James Franck did not appease his wrath; he took exception to a generous obituary and wrote an intemperate rejoinder in a journal. In a letter to Krebs, Max Delbrück expresses his disgust at the manner in which Warburg conducted his polemics and owned that this alone had deterred him from entering the field.

In 1953, Warburg at last took possession of a fine new research institute that the Max-Planck Society had built for him in Dahlem. He was then 70 and was to continue working for another 17 years and 240 papers, up to two days before his death, which was greeted with thunderous eulogies.

Petra Werner has skilfully resurrected the scaly old basilisk for her readers and illuminated a richly interesting period of scientific history. Her book admirably complements Krebs's biographical memoir of 11 years ago (Otto Warburg: Cell Physiologist, Biochemist and Eccentric). There is a well-chosen collection of photographs. The title - an assertion that is not perhaps borne out by the circumstances of Warburg's life (or by that of many other geniuses) - comes from a tribute by M. L. Anson, Warburg's one loyal American admirer.

Walter Gratzer is in the MRC Muscle and Cell Motility Unit, King's College, Drury Lane, London WC2B 5RL, UK.

\section{The politics of our genes}

W. F. Bynum

Eugenics, Human Genetics and Human Failings: The Eugenics Society, its Sources and its Critics in Britain. By Pauline M. H. Mazumdar. Routledge: 1992. Pp. 373. £40, $\$ 74.50$.

IT is an historical commonplace that the eugenics movements of half a century ago were fuelled by race in Germany and the United States, and by class in Britain. American eugenicists were concerned with immigration, especially from Asia and Eastern Europe; German eugenicists with the presence of Jews and other 'non-aryans' in their midst; and the British with their perceived class-related differences in fertility. After the atrocities of the Nazis were exposed, eugenics acquired a dirty name, and post-war science and social policy played down hereditary determinants in favour of social, cultural and environmental ones. And eugenics remains as a salutary tale of ideology and intolerance masquerading as science; repression pretending to be progress.

Like many commonplaces, this one contains the virtue of first-order explanatory power, but little more. As Pauline Mazumdar's study of Britain's Eugenics Society makes clear, there was never a complete consensus among the society's members, either in terms of the 'facts' of human inheritance or the consequences for human betterment to be drawn from them. Nor, in her account, was the revulsion caused by the holocaust a major reason why the Eugenics Society was not the force in the 1950 s that it had been a couple of decades earlier. Rather, she attributes this decline largely to the changed social climate of the early years of the Welfare State, and to the sustained criticism of eugenic methods and assumptions by a number of British scientists, mostly of left-wing politics, and including Lancelot Hogben, J. B. S. Haldane (the centenary of whose birth falls this year) and Lionel Penrose. In particular, the favourite method of the eugenicists - the collecting and evaluation of elaborate human pedigrees was discredited and replaced by the more sophisticated tools of factor analysis and chromosome linkage. These, Hogben insisted, were ethically neutral and could yield a sound science of human heredity. Ironically, they derived much inspiration from German mathematical models - Vererbungsmathematick - and their application to the analysis of human blood groups.

Mazumdar offers a shrewd and largely convincing interpretation of the interplay of politics and science in the work of Hogben, Haldane and Penrose, even if she never actually confronts the issue of why human genetics after the Second World War might be thought to be more value-free than the eugenics it replaced. Insofar as there was an experimentum crucis, it was probably Penrose's survey of 1,280 cases of mental subnormality, carried out in the 1930 s at the Royal Eastern Counties Institution at Colchester. His brief was to examine patients who had been diagnosed as mentally defective and to determine the relative roles of heredity and other factors in the aetiology of their condition. Apart from those with the specific conditions of Down's syndrome and phenylketonuria, he found it impossible to categorize most of the patients with precision, and they had rather boring and unrevealing family histories.

Studies such as Penrose's did much to undermine eugenic claims that pedigree studies unambiguously demonstrated the hereditary nature of many undesirable social traits, and the preponderance of these traits in the social class that was often called the residuum. Nevertheless, Mazumdar correctly emphasizes that any crude polarization of students of human heredity in the 1930 s into eugenic and anti-eugenic camps is misleading. The longtime secretary of the Eugenic Society, Carlos P. Blacker (inexplicably rechristened 'Charles' by Mazumdar) managed to remain on good terms with many who were critical of the society's aims and methods, publishing one of Hogben's papers in a volume he edited, and trying to adapt the society's policies to the political realities of Britain after the Second World War. More generally, eugenicists and their critics often came from similar backgrounds, sat on many of the same committees, saw each other socially and read each other's books and papers. The centre of gravity of much of Mazumdar's book is the senior common room at University College London, where Karl Pearson, Cyril Burt (dubbed 'Cecil' in the index of this book), Haldane and Penrose taught.

This institutional context of eugenics and its critics was presented rather more explicitly in Daniel J. Kevles' In the Name of Eugenics (Knopf, New York 1985; Penguin, London, 1986), and readers of that splendid monograph will find much in Mazumdar's study that is already familiar. They will also recognize that Mazumdar's rather stolid style is a far cry from the lightness of Kevles' erudition. Nevertheless, Mazumdar has not simply been treading in Kevles' footsteps. She offers some new insights into the background of the Eugenics Society, the influence of German mathematics on British geneticists and the changing offi- 